\title{
Interference on Iodine Uptake and Human Thyroid Function by Perchlorate-Contaminated Water and Food
}

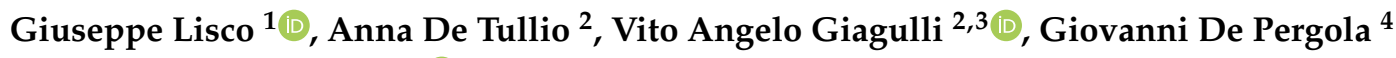 \\ and Vincenzo Triggiani ${ }^{2, *(\mathbb{D})}$ \\ 1 ASL Brindisi, Unit of Endocrinology, Metabolism \& Clinical Nutrition, Hospital "A. Perrino", \\ Strada per Mesagne 7, 72100 Brindisi, Puglia, Italy; g.lisco84@gmail.com \\ 2 Interdisciplinary Department of Medicine-Section of Internal Medicine, Geriatrics, Endocrinology and Rare \\ Diseases, University of Bari “Aldo Moro", School of Medicine, Policlinico, Piazza Giulio Cesare 11, \\ 70124 Bari, Puglia, Italy; annadetullio16@gmail.com (A.D.T.); vitogiagulli58@gmail.com (V.A.G.) \\ 3 Clinic of Endocrinology and Metabolic Disease, Conversano Hospital, Via Edmondo de Amicis 36, \\ 70014 Conversano, Bari, Puglia, Italy \\ 4 Department of Biomedical Sciences and Human Oncology, Section of Internal Medicine and Clinical \\ Oncology, University of Bari Aldo Moro, Piazza Giulio Cesare 11, 70124 Bari, Puglia, Italy; \\ gdepergola@libero.it \\ * Correspondence: vincenzotriggiani@uniba.it
}

Received: 14 May 2020; Accepted: 1 June 2020; Published: 4 June 2020

\begin{abstract}
Background: Perchlorate-induced natrium-iodide symporter (NIS) interference is a well-recognized thyroid disrupting mechanism. It is unclear, however, whether a chronic low-dose exposure to perchlorate delivered by food and drinks may cause thyroid dysfunction in the long term. Thus, the aim of this review was to overview and summarize literature results in order to clarify this issue. Methods: Authors searched PubMed/MEDLINE, Scopus, Web of Science, institutional websites and Google until April 2020 for relevant information about the fundamental mechanism of the thyroid NIS interference induced by orally consumed perchlorate compounds and its clinical consequences. Results: Food and drinking water should be considered relevant sources of perchlorate. Despite some controversies, cross-sectional studies demonstrated that perchlorate exposure affects thyroid hormone synthesis in infants, adolescents and adults, particularly in the case of underlying thyroid diseases and iodine insufficiency. An exaggerated exposure to perchlorate during pregnancy leads to a worse neurocognitive and behavioral development outcome in infants, regardless of maternal thyroid hormone levels. Discussion and conclusion: The effects of a chronic low-dose perchlorate exposure on thyroid homeostasis remain still unclear, leading to concerns especially for highly sensitive patients. Specific studies are needed to clarify this issue, aiming to better define strategies of detection and prevention.
\end{abstract}

Keywords: perchlorate; Natrium/Iodide symporter; iodine; endocrine disruptors; review; drinking and Food; Hypothyroidism

\section{Introduction}

Endocrine disrupting chemicals (EDCs) have been defined as a group of compounds or a mixture of natural or man-housed exogenous chemicals which interfere with the hormonal network, or induce endocrine cell damage [1]. Interference may be attributable to several mechanisms such as receptor agonism or antagonism, modulation of receptor expression, modification of signal transduction, hormone synthesis or incretion, plasmatic distribution and clearance [2]. Moreover, epigenetic effects 
have been hypothesized for EDCs and concerns about a possible "transmission" of EDCs across the generations is a topic of debate $[3,4]$. To date, a wide range of environmental chemicals have been identified as being involved in the pathogenesis of thyroid diseases $[5,6]$ and several chemicals or common pollutants may act as thyroid disruptors [7-9]. Perfluorooctanoic acid [10], a chemical largely employed for the manufacturing of waxes, cosmetics, carpets, cleaning or waterproof products, and bisphenols [11], hugely used as plasticizers, were found to increase the prevalence of thyroid diseases in exposed patients [12], including thyroid autoimmunity [13]. Moreover, legacy pesticides were experimentally shown to affect thyroid function [14] and, despite some controversy, they may also induce hypothyroidism, thyroid autoimmunity, thyroid volume enlargement or nodules in humans [15]. The bactericide triclosan was mostly found in personal hygiene products (oral care, shampoos, hand sanitizers, soaps), and was proven to increase the risk of thyroid diseases, too [16]. Thyroid disruption includes different pathways, and may be due to either interference or synergism among different EDCs [17]. The leading mechanisms of thyroid interference by pollutant agents have been explored, and frequently include the inhibition of thyroperoxidase activity, competitive natrium-iodide symporter (NIS) inhibition, impairment of binding protein transport and peripheral deiodinase activity, enhancement of liver catabolism [18]. Since food and drinks are also a relevant source of thyroid disruptors, a lifelong human exposure to these chemicals could induce potentially harmful consequences on thyroidal homeostasis. Given this consideration, this review aims to specifically focalize on NIS interference by specific agents, mainly perchlorate compounds, which are commonly found in food and drinks.

\section{Materials and Methods}

The authors summarized iodine metabolism and its importance in thyroid homeostasis and hormonal synthesis. Furthermore, the authors searched PubMed/MEDLINE, Scopus, Web of Science, institutional websites and Google for relevant information about the fundamental mechanism of NIS interference induced by perchlorate compounds orally assumed and the consequences on thyroidal health status associated with chronic exposure to these chemicals.

\section{Results}

\subsection{Overview on Iodine Metabolism in Healthy Humans}

The primary source of iodine (I) is represented by natural food (seafood, milk, eggs, vegetables, legumes, fruits), fortified food (salt) and mineral waters. I is basically available in two forms, organic and inorganic (iodide); the latter form is absorbed at the level of stomach and duodenum [19] through a specific natrium-iodide symporter (NIS) which regulates iodine homeostasis in human body [20]. After gastrointestinal absorption, I enters the circulation, undergoing to a large distribution into the plasma, red blood cell cytoplasm and extracellular fluid, and is finally intercepted by tissues [21]. A wide range of tissues express the NIS, including salivary glands, breast, and thyroid [22]. Nevertheless, thyroid represents the most important reservoir of the ion considering that, in a healthy human body, the gland normally stores up to $80 \%$ of the entire iodine pool (15-20 mg). The NIS is a 13-domain transmembrane protein which mediates transmembrane I and sodium (1 to 2 ratio) transport at the level of thyrocyte's basolateral membrane [23,24]. Transmembrane sodium gradient is generated by the sodium-potassium ATPase pump which indirectly provides energy for an almost continuous intrathyroidal I uptake (secondary active transport). Given this thyroid avidity, I concentration in thyrocytes is 30 to 60 times higher than its plasmatic levels [25]. As a mean, thyroid secretes $80 \mu \mathrm{g}$ a day of I in the form of both levothyroxine and triiodothyronine [26]. Due to peripheral metabolism of thyroid hormones, I circulates in bloodstream finally undergoing to both renal and hepato-biliary clearance and thyroidal re-uptake, as well. An intrathyroidal I recycling has also been described [27]. Thyroidal uptake considerably fluctuates according to I intake, and ranges from $10 \%$ to over $80 \%$ of the entire amount of ingested I. Contrariwise, urinary I excretion is inversely correlated with thyroid 
uptake, and in the case of adequate I intake, more than $90 \%$ of the ion is cleared by the kidneys with urine [28]. Urinary I concentration is thus a reliable biomarker of I intake, and is a useful tool for screening patients suspected for I deficiency [25]. Both the thyroid hormone synthesis and urinary I excretion increase during pregnancy [29], while 126 to $269 \mu \mathrm{g}$ of I could be excreted with each liter of breast milk in lactating women [30]. Iodine intake is generally recommended at $150 \mu \mathrm{g}$ per day for adults in order to ensure the daily iodine recycle [31]. Thus, the recommended dose of iodine intake raises at $200-250 \mu \mathrm{g}$ per day during pregnancy and lactation for sustaining an increased requirement [32]. I is an essential micronutrient for thyroid hormones synthesis [33,34]. Afterward the transition into thyrocyte cytoplasm, I moves towards the apical surface of thyrocyte's plasmatic membrane into the follicular lumen. This transport is mediated by a ionic carrier belonging to the SLC26A family, otherwise known as pendrin [35], and is also expressed at the level of the inner ear, kidney and bowel. Specifically, pendrin is essential for favoring the efflux of iodine into follicular space in exchange of chloride (1 to 1 ratio) and a defective synthesis or function of this carrier is responsible for a the so called Pendred's syndrome [36]. Once into follicular lumen, I undergoes oxidation by thyroperoxidase, thus becoming promptly available for thyroglobulin's organification. Thyroid I content is the most important regulator of thyroid hormone synthesis. Indeed, I overload reduces the expression of NIS, decreases both the thyroid peroxidase and deiodinases activities, and finally leads to a transient impairment of thyroid hormone synthesis [37]. In predisposed patients, iodine excess increases oxidative stress, and may induce or exacerbate thyroid autoimmunity and hypothyroidism (Wolff-Chaikoff effect) [38]. Finally, I overload may exacerbate a latent hyperthyroidism in patient with single thyroid nodule or multinodular goiter [39].

\subsection{Perchlorate Compounds and Iodine Interference}

The evidence that high doses of perchlorate $\left(\mathrm{ClO}_{4}{ }^{-}\right)$anion decreased thyroid hormone synthesis has been known since the 1950s [40], and given this peculiarity, it has been used to effectively treat hyperthyroidism such as in Graves' disease and amiodarone-induced hyperthyroidism [41]. Specifically, $\mathrm{ClO}_{4}{ }^{-}$competes with I at the level of the NIS (Figure A1), the former having a 30-fold higher affinity for the symporter when compared to the latter [42]. A dose-response sigmoid curve has been reported for describing NIS sensitivity to $\mathrm{ClO}_{4}{ }^{-}$inhibition in different species and the half maximal inhibiting concentration in humans was found at $1.566 \mu \mathrm{M}$ [43]. To confirm these experimental results, an orally delivered acute exposure to up to $520 \mu \mathrm{g} / \mathrm{kg}$ of body weight (bw) induced a significant increase in serum thyroid stimulating hormone (TSH) levels, with a relevant decline in serum-free levothyroxine concentrations [44]. On the other hand, it is thought that a chronic low-dose exposure to $\mathrm{ClO}_{4}{ }^{-}$, normally observed as the consequence of food and drink intake, could impair thyroid function by reducing iodine uptake particularly in predisposed individuals, such as those with an underlying iodine deficiency $[45,46]$.

\subsection{Perchlorate Compounds in Food and Water}

$\mathrm{ClO}_{4}{ }^{-}$may naturally occur in the atmosphere from spontaneous photogenic reaction between chloride and ozone, or arises from man-made products such as oxidizers, fertilizers, explosives, propellants, fireworks, airbag inflators spread into environment. In addition, $\mathrm{ClO}_{4}^{-}$can be also produced from the degradation of the common water disinfectant hypochlorite [47]. Perchlorate compounds occur in different form, such as metal perchlorate, ammonium and alkali metal forms, organic and inorganic forms and salts. Antarctic ice represents the most important sediment of $\mathrm{ClO}_{4}{ }^{-}$in the planet, with different concentrations depending on drilling areas [48]. The Atacama desert (Chile, South America) is another important natural source of geogenic $\mathrm{ClO}_{4}{ }^{-}$, and elevated concentrations of its compounds have been found in soil (290 to $2565 \mu \mathrm{g} / \mathrm{Kg}$ ) and surface waters $(744$ to $1480 \mu \mathrm{g} / \mathrm{L})$ [49]. Other relevant sources of natural $\mathrm{ClO}_{4}{ }^{-}$have been discovered in Alaska, Puerto Rico, New Mexico, Texas, California (United States of America, USA), and Bolivia (South America). Anthropogenic $\mathrm{ClO}_{4}^{-}$compounds have been found in soil, sea and rainwater, 
surface and groundwaters, indoor and outdoor dust, ice and snow [50]. Given data from ice drilling analyses, anthropogenic $\mathrm{ClO}_{4}{ }^{-}$started to accumulate in Arctic ice from the 1980s [51]. In Devon Island (Canada, North America), $\mathrm{ClO}_{4}{ }^{-}$compounds were found in ice and snow at variable concentrations ranging from 1 to $18 \mathrm{ng} / \mathrm{L}$ [52]. A great variability in rainwater $\mathrm{ClO}_{4}^{-}$levels was observed due to differences in analyzed geographical sites and seasonality. In fact, $\mathrm{ClO}_{4}{ }^{-}$concentration ranges from 0.02 to $1.6 \mu \mathrm{g} / \mathrm{L}$ in Texas (USA) [53], 0.02 to $6.9 \mu \mathrm{g} / \mathrm{L}$ in India (Asia) [54], and 0.35 to $27.3 \mathrm{ng} / \mathrm{mL}$ in China (Asia) [55]. Moreover, Munster et al. evaluated the levels $\mathrm{ClO}_{4}{ }^{-}$in total deposition from November 2005 to July 2007 in Long Island (New York State), relieving a mean concertation of $0.21 \mu \mathrm{g} / \mathrm{L}$ and with a maximum level of $2.81 \mu \mathrm{g} / \mathrm{L}$ recorded after fireworks displays occurred during the Independence day celebration [56]. Another observation reported different levels of $\mathrm{ClO}_{4}{ }^{-}$in wet deposition only, ranging from $<5$ to $105 \mathrm{ng} / \mathrm{L}$ (mean $14 \mathrm{ng} / \mathrm{L}$ ) with higher concentrations recorded in spring and summer than winter [57]. Soil usually does not retain $\mathrm{ClO}_{4}{ }^{-}$and more than $90 \%$ is confined in the aqueous phase [58] where $\mathrm{ClO}_{4}{ }^{-}$spreads and persists due to its high solubility and resistance to photolysis and anaerobic bacterial biodegradation [59]. Fruits and vegetables represent a relevant food source of $\mathrm{ClO}_{4}{ }^{-}$, particularly because of the widespread use of perchlorate-based fertilizers [60]. In particular, leafy vegetables, spinach, salad plants, raspberries, apricots, asparagus, cantaloupes, and tomatoes accumulate $\mathrm{ClO}_{4}{ }^{-}$as a consequence of farming techniques [61]. The mean concentration of perchlorate in tested food appears variable and the highest levels have been found in Guatemalan cantaloupes $(156 \mu \mathrm{g} / \mathrm{Kg})$, spinach $(133 \mu \mathrm{g} / \mathrm{Kg})$, Chilean green grapes $(45.5 \mu \mathrm{g} / \mathrm{Kg})$ and Romaine lettuce $(29 \mu \mathrm{g} / \mathrm{Kg})$ [62]. Vega et al. reported variable concentration of $\mathrm{ClO}_{4}{ }^{-}$in Chilean drinking waters which ranged from 4 to $120 \mu \mathrm{g} / \mathrm{L}$ [63]. Conversely, lower levels of $\mathrm{ClO}_{4}{ }^{-}$in drinking water have been observed in the USA [64] and Europe, including Italy $(0.5-75 \mu \mathrm{g} / \mathrm{L})$ [65].

\subsection{Chronic Esposure to Perchlorate Compounds by Food and Drinking Water}

The 2018 "Italian Institute for Food and Agriculture Market Services" ranking reported the USA as the most valuable country in exporting fruits and vegetables, followed by Mexico and Chile. Given the volume of exports, Spain (4th) and Italy (7th) are responsible for the $42 \%$ of the entire European market of fruits and vegetables, ahead of Poland, France and Greece [66]. Chile has a remarkable export economy [67], and usually exports several thousands of millions of kilograms of fruits a year worldwide [68]. Specifically, the European Union is Chile's third-largest trade partner in the world, after China and the USA, and currently imports 19\% of the Chilean global export of vegetable products [69]. Cherries and table grapes, followed by apples, Chilean blueberries and plums are the most exported vegetable products to Europe. Vegetables from Chile are notoriously rich in $\mathrm{ClO}_{4}{ }^{-}$and the excessive consumption of these products could have chronically negative consequences on thyroid homeostasis. Indeed, $\mathrm{ClO}_{4}{ }^{-}$food exposure is essentially driven by vegetables and fruits and widely ranged according to geographical area as well as seasonality [70]. To confirm this assumption, $\mathrm{ClO}_{4}{ }^{-}$was detected in a wide range of vegetable samples, ranging from 21 to $162 \mu \mathrm{g} / \mathrm{kg}$ [71]. Vegetables consumption in Italy seems to slightly but continuously increase over time and some of the most consumed vegetable products, such as spinach, leaf vegetables and spices were found to be a relevant source of $\mathrm{ClO}_{4}^{-}$[72]. Normal consumption of these vegetables does not usually lead to exceeding the maximal total daily dose according to the European Food Safety Authority $2014(0.3 \mu \mathrm{g} / \mathrm{Kg}$ of bw). However, a higher daily consumption of these products led to a relevant exceeding of the maximal tolerated dose by 32\% in adults, $61 \%$ in children and 56\% in infant [72]. In addition, tea and herbal infusions could represent another relevant source of $\mathrm{ClO}_{4}{ }^{-}$, oscillating from 630 to $730 \mu \mathrm{g} / \mathrm{Kg}$ for dark tea; 80 to $430 \mu \mathrm{g} / \mathrm{Kg}$ for black tea; and 250 to $500 \mu \mathrm{g} / \mathrm{Kg}$ for green tea [73]. Therefore, the consumption of the aforementioned products should be moderate and intermittent for avoiding a consistent $\mathrm{ClO}_{4}{ }^{-}$overload. Indeed, acute exposure to high or very high levels of $\mathrm{ClO}_{4}{ }^{-}$ normally is not enough for overcoming thyroidal compensation and ability to maintain normal serum concentration of thyroid hormones in healthy individuals [64]. Chronic consumption of $\mathrm{ClO}_{4}^{-}$in adults has been estimated as high as 0.07 to $0.34 \mu \mathrm{g} / \mathrm{Kg}$ of body weight per day in Europe [70], and 0.2 
to $0.4 \mu \mathrm{g} / \mathrm{Kg}$ of body weight per day in the USA [74]. Despite $\mathrm{ClO}_{4}{ }^{-}$consumption being generally below the level of recommended reference dose in adults [75], it may become critical, especially in some categories, such as children, high sensitive patients, cigarette smokers, iodine deficient people, and pregnant and breast feeding women as well [76-78]. Indeed, the inhibition of I uptake and any potential downstream effects induced by $\mathrm{ClO}_{4}{ }^{-}$are strictly dependent on the exposure to other environmental NIS inhibitors, such as thiocyanates and nitrates, and iodine intake itself [79]. These potential confounders should therefore be considered in future studies and calculations for risk assessment [80]. Finally, breast milk and infant formulas are the most significant sources of $\mathrm{ClO}_{4}{ }^{-}$for newborns and infants [81-83]. Compared with adults, infants and children exhibited a greater $\mathrm{ClO}_{4}{ }^{-}$exposure per $\mathrm{Kg}$ of bw per day [75,84], particularly breastfed children $(0.22 \mu \mathrm{g} / \mathrm{Kg}$ of $\mathrm{bw} /$ day) respective to those fed by cow milk-based formula $(0.1 \mu \mathrm{g} / \mathrm{Kg}$ of bw/day) or soy-based formula $(0.027 \mu \mathrm{g} / \mathrm{Kg}$ of bw/day) [85]. Food intake more than drinking water is considered the main source of $\mathrm{ClO}_{4}{ }^{-}$for children [81] and adults [86], since $\mathrm{ClO}_{4}{ }^{-}$exposure from drinking water alone is not able to suppress thyroid function [87]. Nevertheless, this assumption is controversial considering that other results suggest opposite conclusions [70,74].

\subsection{Perchlorate Compounds Toxicity}

From this point of view, concerns have been supposed in case of $\mathrm{ClO}_{4}{ }^{-}$exposure during fetal and infantile life $[88,89]$. The placental NIS ensures maternal-to-fetal transition of I [90], therefore allowing fetal uptake of $\mathrm{ClO}_{4}{ }^{-}$and other goitrogen chemicals, too. Blount et al. specifically analyzed the perinatal exposure to goitrogen chemicals in 150 mothers from New Jersey (USA), showing that the placental barrier was more permeable to I respective to goitrogens and maternal urinary $\mathrm{ClO}_{4}{ }^{-}$ concentrations were directly correlated with $\mathrm{ClO}_{4}{ }^{-}$concentration in amniotic fluid, thus resulting an useful tool for assessing fetal exposure [91]. As observed in a Chinese population, $\mathrm{ClO}_{4}{ }^{-}$was detected in infant's urine $(22.4 \mathrm{ng} / \mathrm{mL})$ and cord blood serum $(3.2 \mathrm{ng} / \mathrm{mL})$ at a concentration about 22 times greater compared to that reported by Blount $(0.14 \mu \mathrm{g} / \mathrm{L})$ [92]. This finding is difficult to explain, but could be attributable to different environmental exposures or dissimilarities in assay or both. Several studies analyzed the impact of a mild-to-moderate exposure to $\mathrm{ClO}_{4}{ }^{-}$in early pregnancy on both maternal thyroid function and several neonatal outcomes. In a cross-sectional trial in Athens (Greece), 139 first-trimester pregnant women with mild iodine deficiency were chronically exposed to dietary sources of $\mathrm{ClO}_{4}{ }^{-}$as suggested by median levels of urinary $\mathrm{ClO}_{4}{ }^{-}$concentration at around $4 \mu \mathrm{g} / \mathrm{L}$. The authors specifically found that $\mathrm{ClO}_{4}{ }^{-}$urinary concentration, possibly associated with a moderate iodine deficiency, was inversely related with plasmatic levels of triiodothyronine and thyroxin in this cluster of patients [93]. A cross-sectional study in 200 first-trimester Thai pregnant women $(<14$ weeks of gestation age) confirmed a chronic low-level environmental exposure to $\mathrm{ClO}_{4}^{-}$compounds (and thiocyanates) and this exposure was positively associated with serum TSH concentration and negatively related with serum levothyroxine levels [94]. Data from San Diego (South California) reported a mean urinary $\mathrm{ClO}_{4}{ }^{-}$concentration of $8.5 \mu \mathrm{g} / \mathrm{L}$ in first-trimester pregnant women, and the higher the level of $\mathrm{ClO}_{4}{ }^{-}$, the higher the level of TSH and the lower those of total thyroxine and free thyroxine [95]. Pearce et al. analyzed the effects of environmental exposure to $\mathrm{ClO}_{4}{ }^{-}$in a cohort of 1600 first-trimester pregnant women, with mild-to-moderate iodine deficiency, who had been enrolled in the Controlled Antenatal Thyroid Screening Study (CATS) from Cardiff (Wales) and Turin (Italy). The results of this observation displayed a low-level environment exposure to $\mathrm{ClO}_{4}{ }^{-}$in all participants but no thyroidal impairment due to this contamination was noted [96]. These findings were also confirmed in first-trimester pregnant women from Los Angeles (California) and Cordoba (Argentina) in whom a low concentration of urinary $\mathrm{ClO}_{4}{ }^{-}$were detected (mean of 7.8 and $13.5 \mu \mathrm{g} / \mathrm{L}$, respectively) but no correlation with $\mathrm{ClO}_{4}{ }^{-}$exposure and thyroid function was demonstrated [97]. A cross-sectional association between urinary $\mathrm{ClO}_{4}{ }^{-}$, thiocyanate and nitrate concentration and thyroid function was also assessed in healthy pregnant women living in New York City (New York State). The results confirm that a co-occurrent exposure to $\mathrm{ClO}_{4}{ }^{-}$, thiocyanate and 
nitrate may possibly impair thyroid homeostasis leading to hypothyroidism and $\mathrm{ClO}_{4}{ }^{-}$specifically displayed the largest weight in driving this outcome [98]. Taylor et al. evaluated the relationship between maternal $\mathrm{ClO}_{4}{ }^{-}$exposure and neurocognitive development in first-trimester pregnant women with hypothyroidism or hypothyroxinemia and mild iodine deficiency. The results display that maternal urinary $\mathrm{ClO}_{4}{ }^{-}$concentration in the highest $10 \%$ of the population were associated with an higher risk of offspring's verbal intellective quotient impairment [odds ratio 3.14 (1.38-7.13), p 0.006] and levothyroxine replacement did not improve the outcome [99]. In addition, a high risk of mild reduction in the verbal intellective quotient in 3-year-old children who were prenatally exposed to $\mathrm{ClO}_{4}^{-}$was observed irrespective of their mother's thyroid function during pregnancy [100]. Furthermore, maternal $\mathrm{ClO}_{4}^{-}$concentration was found to positively correlate with male infant bodyweight, especially in preterm [101].

Several observations assessed the relationship between maternal perchlorate exposure and neonatal or infant thyroid homeostasis with controversial results according to the different clinical end-points used for the assessment of euthyroidism [102-104]. $\mathrm{ClO}_{4}{ }^{-}$may affect children growth as reported by Mervish et al., who observed that girls with higher $\mathrm{ClO}_{4}{ }^{-}$exposure displayed lower body mass index and waist circumference than controls [105]. In addition, the results of a cross-sectional study in 3151 participants (12-80 years old) displayed for each logarithmic unit increased exposure to both $\mathrm{ClO}_{4}{ }^{-}$and thiocyanate, the level of free thyroxine decreased by $8 \%$ in adolescent girls and $9 \%$ in adolescent boys, respectively [106].

\subsection{Overview on Other Halogenate Compounds}

Other halogenated compounds may interfere with I uptake as similarly observed for $\mathrm{ClO}_{4}{ }^{-}$, including bromine and brominated compounds [107] and fluoride and fluorinated compounds [108]. Bromine compounds naturally occur in marine and terrestrial plants, but industrial compounds account for $80 \%$ of bromine production [109]. In particular, bromine compounds are essentially found in phytochemical, pharmaceutics, pesticides, dyes, and photographic and water treatment chemicals [109]. Bromine has been found at higher concentrations in seawater $(65$ to $80 \mathrm{mg} / \mathrm{L})$ compared to natural waters (in mean $0.5 \mathrm{mg} / \mathrm{L}$ ) and groundwaters ( 1 to several $\mathrm{mg} / \mathrm{L}$ ) [110]. In addition, potassium bromate is an inexpensive oxidizing agent used as dough improver in the baking industry [111]. Specifically, it leads to the formation of disulfide bonds between gluten proteins, ameliorating bread's proprieties, such as swelling and volume [112]. Chronic exposure to potassium bromate was associated with toxic effects and carcinogenicity in animal models [113-115]. However, no data are currently available to also confirm toxicity and carcinogenicity in humans, thus the International Agency for Research on Cancer classified potassium bromate in group 2B (possibly carcinogen to humans) [116]. Given these considerations, potassium bromate has been precautionarily banned from several countries, such as those in Europe, the United Kingdom, Canada, Nigeria, China, South Korea, and several countries in South America, but it is still considered safe in the United States. Indeed, according to the Food and Drug Administration, no sufficient evidence of potassium bromate adverse effects has been collected in humans thus allowing the use of additives in the bread baking industry not exceeding 75 parts per million [117]. For this reason, bromate levels should be constantly and reliably monitored in bread whether potassium bromate has been used as an additive in flour processing [112]. In one observational study in Nanchang (China), bromine was detected in all 131 whole blood samples, thus suggesting a higher prevalence of contamination among people [84]. The daily intake of bromide ranged from 2 to $8 \mathrm{mg}$ in the USA and $9 \mathrm{mg}$ in Europe (the Netherlands) [110]. Regulatory agencies defined limits of concentration bromide in drinking-waters at $6 \mathrm{mg} / \mathrm{L}$ for adults and $2 \mathrm{mg} / \mathrm{L}$ for children and acceptable daily intake currently ranges from 0 to $1 \mathrm{mg} / \mathrm{Kg}$ of bw [110]. Human exposure to brominated compounds usually occurs by food intake and consistently increases over time, resulting particularly higher in Occidental countries [118]. Breast milk as well as hair and adipose tissue may accumulate these chemicals, thus resulting as reservoirs for further persistence of brominated compounds in the human body [118]. Bromide may interfere with thyroid homeostasis, particularly competing with I uptake and 
I clearance $[119,120]$ however, human toxicity data demonstrated that polybrominated compounds may interfere with gonadal function and sexual steroids' metabolism [118]. Fluoride and fluorinated compounds has been found in different rock-forming minerals, fertilizers, pesticides, and propellants, and has also been found in drinking water generally at acceptable levels according to regulatory agencies $(<1.5 \mathrm{mg} / \mathrm{L}$ or $<4 \mathrm{mg} / \mathrm{L})$ [121] and groundwater [122]. Considering that a low dose of fluoride increases overall oral health, several countries add it to their public water supply at 0.7 to $1.5 \mathrm{mg} / \mathrm{L}$ [118]. In Italy, public waters are naturally rich in fluoride $(1 \mathrm{mg} / \mathrm{L})$, thus making fluoride addition in public supply unnecessary [123]. However, fluoride concentration in public waters differs among regions, and is particularly higher in Lazio, where an excessive consumption of public drinking-water may lead to a fluoride overexposure [123]. Concerns over fluoride overexposure through drinking water have been raised in several countries [124], in which the levels of fluoride intake exceed safety limits, leading to a relevant increase in the prevalence of both dental and skeletal fluorosis [125]. Fluoride has been found to block I uptake by two fundamental mechanisms: inhibition of sodium-potassium ATPase and a cytokine-mediated reduction in NIS gene expression [126]. Indeed, fluoride exposure in early stages of life, mostly for preventing dental caries, is believed to be linked with an higher risk of future development of several diseases, including hypothyroidism and impaired intellective quotient [127]. Moreover, the exposure to fluoride concentration at $100 \mathrm{ppm}$ $(\mathrm{mg} / \mathrm{L})$ in experimental conditions were associated with apoptosis, organelle damage and oxidative stress resulting in neurodegeneration, endocrine dysfunction and diabetes mellitus [128]. Due to anthropogenic and industrial activities, a great number of pollutant entry in water systems leading to possible concerns for wildlife and human health. Defluoridation of water may contribute in reducing the level of fluoride contamination in water and different physicochemical and electrochemical methods have been used for this purpose [129]. Among these, biosorption should be considered an easily available, recyclable and inexpensive tool [129].

\section{Discussion}

I sufficiency and euthyroidism are essential for preventing negative neurodevelopmental [130] outcomes and processing disorders [131], thus I deficiency or interference should be hazardous particularly during pregnancy and earlier stages of life given the particularly vulnerable thyroid function in this developmental phase. Conventionally, I deficiency has been defined as a 24-h urinary excretion $<100 \mu \mathrm{g} / \mathrm{L}$ [132]. Given this criteria, more than 2 billion people worldwide are at high risk of iodine insufficiency and at least half of European citizens exhibit a mild to moderate I deficiency [133]. Italy has been historically defined as being endemic for I deficiency, particularly in the northern mountainous regions. Strategies of implementation of iodine intake have been allowed by law since 1972 through the use, on a voluntary basis, of fortified salt with an I content of $15 \mu \mathrm{g} / \mathrm{Kg}$, subsequently augmented to $30 \mu \mathrm{g} / \mathrm{kg}$ (law 55/2005). Supplementation provided a slow but progressive improvement of iodine status over time but did not completely eradicate the risk [134,135] and the prevalence of mild-to-moderate I deficiency remains a current matter [136], especially in pregnancy and lactation [137]. Of note, patients with I deficiency should be considered as highly susceptible for developing I interference by food intake. $\mathrm{ClO}_{4}{ }^{-}$has a short half-life (up to $8 \mathrm{~h}$ ) due to a quick renal clearance [138], thus its accumulation in human body is clearly due to chronic exposure to drinks and food $[139,140] . \mathrm{ClO}_{4}{ }^{-}$exposure may be harmful for thyroid homeostasis, especially in childhood and pregnancy. Two trials were performed to assess short term effects of a $\mathrm{ClO}_{4}{ }^{-}$acute exposure ( 2 weeks) to either 0.5 or $3 \mathrm{mg}$ daily, showing no effect on thyroid function [141,142]. However, 2 weeks of $\mathrm{ClO}_{4}{ }^{-}$exposure at higher doses (10 to $30 \mathrm{mg}$ per day) resulted in significantly reduced iodine uptake, potentially affecting thyroid hormone synthesis [143,144]. The results of these studies should be interpreted with caution, particularly considering that short-term exposure is usually insufficient to affect thyroid secretion of levothyroxine. Moreover, to achieve these levels of exposure, it could be necessary to have an extremely high daily consumption of $\mathrm{ClO}_{4}{ }^{-}$for a limited period of time which is normally not reproducible in real life (i.e., 2 litres of drinking water at $\mathrm{ClO}_{4}{ }^{-}$content as 
high as $200 \mu \mathrm{g} / \mathrm{L})$. On the other hand, studies which assessed the effect of a chronic $\mathrm{ClO}_{4}{ }^{-}$exposure (i.e., occupational) on thyroid hormone synthesis reported inclusive or equivocal results, despite I uptake being usually impaired in almost all participants [145-147]. Given these findings, it was difficult to make an unequivocal conclusion. The National Research Council of the National Academics sustained that, in healthy individuals, I uptake would be reduced by at least $75 \%$ for months in order to significantly impair thyroid hormone synthesis [47]. Thus, a sustained exposure to $0.5 \mathrm{mg} / \mathrm{Kg}$ of bw/day of $\mathrm{ClO}_{4}^{-}$would be most likely to induce a significant decline in I uptake consequentlyaffecting thyroid hormone synthesis [47]. However, the US Environmental Protection Agency adopted a recommended reference dose for $\mathrm{ClO}_{4}{ }^{-}$at $0.7 \mu \mathrm{g} / \mathrm{kg}$ of bw/day [141]. This conservative decision was based upon a non-observed effect level found by Greer et al. in 2002 (7 $\mu \mathrm{g} / \mathrm{Kg}$ of bw/day) divided for an uncertainty factor of 10 attributable to intra-human variability intended to calculate an acceptable daily intake [144]. The Office of Environmental Health Hazards Assessment developed a public health target for $\mathrm{ClO}_{4}{ }^{-}$in drinking water of $6 \mu \mathrm{g} / \mathrm{L}$ in 2002 to $1 \mu \mathrm{g} / \mathrm{L}$ in 2012 [148]. In 2011, the Joint Food and Agriculture Organization-World Health Organization recognized a maximum tolerable daily intake of $10 \mu \mathrm{g} / \mathrm{kg}$ of body weight [149]. In Europe (France and Germany), the acceptable level of exposure to $\mathrm{ClO}_{4}^{-}$was set at $0.7 \mu \mathrm{g} / \mathrm{kg}$ of bw with a tolerable concentration in drinking water of $15 \mu \mathrm{g} / \mathrm{L}$, successively reduced to $4 \mu \mathrm{g} / \mathrm{L}$ [47]. Furthermore, the European Food Safety Authority in 2014 predisposed the maximum tolerable daily dose of $0.3 \mu \mathrm{g} / \mathrm{Kg}$ of bw/day [70]. Water and soil contaminations have become a concern due to detrimental consequences for both wildlife and human health. Efficient methods for reducing the levels of $\mathrm{ClO}_{4}{ }^{-}$in fruits and vegetables represent useful tools to decrease the levels of exposure. Considering that the contamination of fruits and vegetables should reflect $\mathrm{ClO}_{4}{ }^{-}$concentration in soil, water for irrigation and fertilizers, several processes found application in this field [150]. As an example, ion exchangers, which replace $\mathrm{ClO}_{4}{ }^{-}$with other resident anions, such as bicarbonate, sulfate and nitrate, are one of the most used methods for removing $\mathrm{ClO}_{4}{ }^{-}$ from water and may be considered as a tool for dropping $\mathrm{ClO}_{4}{ }^{-}$levels throughout soil watering [151]. Biological degradation by perchlorate-reductase producer bacteria [152] or plants [150] could be counted as another useful method for reducing $\mathrm{ClO}_{4}{ }^{-}$in water and soil, respectively. Photocatalytic reduction of aqueous oxyanions converts toxic anions (such as $\mathrm{ClO}_{4}{ }^{-}$or bromate) into harmless and less and/or not toxic ions in contaminated waters [153]. However, several limitations have been described for this method, which include high costs of technologies, sunlight harvesting capability and generation of dangerous radical substances [153]. Physical methods include reverse osmosis coupled with nanofiltration membrane systems [154], or a less expensive semipermeable membrane system coupled with electrodialysis [155]. Moreover, iron-media adsorbent have been used for removing $\mathrm{ClO}_{4}{ }^{-}$and other anions in aqueous solutions [156]. In particular, granular ferric hydroxide was found to induce a rapid uptake of $\mathrm{ClO}_{4}{ }^{-}$in water, considering that its maximum absorption and equilibrium were achieved in 30 and $60 \mathrm{~min}$, respectively at $25{ }^{\circ} \mathrm{C}$ with optimal pH at 3-7 [157]. $\mathrm{ClO}_{4}{ }^{-}$contamination of soil and water is strictly related to geogenic $\mathrm{ClO}_{4}{ }^{-}$naturally occurred in the atmosphere and subsequently precipitated. However, fertilizes may be considered a source of $\mathrm{ClO}_{4}{ }^{-}$accumulated in food chain [158]. Among fertilizers, higher levels of $\mathrm{ClO}_{4}{ }^{-}$were detected in nitrogenous fertilizers $(32.6 \mathrm{mg} / \mathrm{Kg})$ compared to natrium-phosphorus-potassium $(12.6 \mathrm{mg} / \mathrm{Kg})$, non-nitrogen $(10.2 \mathrm{mg} / \mathrm{Kg})$ and phosphates $(11.5 \mathrm{mg} / \mathrm{Kg})$ fertilizers [159]. Thus, the type and the amount of fertilizer may influence the source of entry for $\mathrm{ClO}_{4}{ }^{-}$in crops. Additionally, agronomic practices of fertilization may also contribute in this risk. As an example, fertigation is an innovative and less expensive methods of fertilization which allows for less water being wasted, better distribution of fertilizers and superior micronutrient assimilation by crops, but given these principles, it may be easier to foster more significant accumulations of $\mathrm{ClO}_{4}$ - in fruits and vegetables [60].

\section{Conclusions}

In conclusion, acute exposure to $\mathrm{ClO}_{4}{ }^{-}$by food and drink should not be a harmful concern for thyroid homeostasis in healthy individuals. Generally, chronic exposure to $\mathrm{ClO}_{4}^{-}$by eating 
and drinking does not exceed the safety reference levels. However, lifelong effects of a low-dose exposure to $\mathrm{ClO}_{4}{ }^{-}$are currently unknown and concerns remain, especially for highly susceptible individuals such as pregnant and breastfeeding women, infants and children, cigarette smokers and high vegetable consumers, such as vegans. These clusters of patients should be advised about this worry, and encouraged to limit daily consumption of rich in perchlorate vegetables, as well as to implement I intake.

On the other hand, producers should be encouraged to use specific culture systems, fertilizers (as an example nitrate-free) as well as technologies for reducing the level of $\mathrm{ClO}_{4}{ }^{-}$in soil and irrigation waters in order to prevent an unnecessary $\mathrm{ClO}_{4}{ }^{-}$enrichment of crops. For this purpose, economic sustainment should be considered particularly for small and medium-size companies in order to reduce management costs.

Finally, further and specific long-term studies are probably needed to better explore this issue, aiming to clarify whether monitoring of perchlorate exposure over time, especially in individuals at risk, could be of interest for endocrinologists for better defining strategies of detection and prevention in exposed patients.

Author Contributions: V.T. conceived the review. V.T., G.L. and A.D.T. provided database search. G.L. and A.D.T. drafted the manuscript. All the authors (V.T., G.L., A.D.T., V.A.G., G.D.P.) read, gave feedback, and approved the final manuscript. All authors have read and agreed to the published version of the manuscript.

Funding: This research received no external funding.

Conflicts of Interest: The authors declare no conflict of interest.

\section{Appendix A}

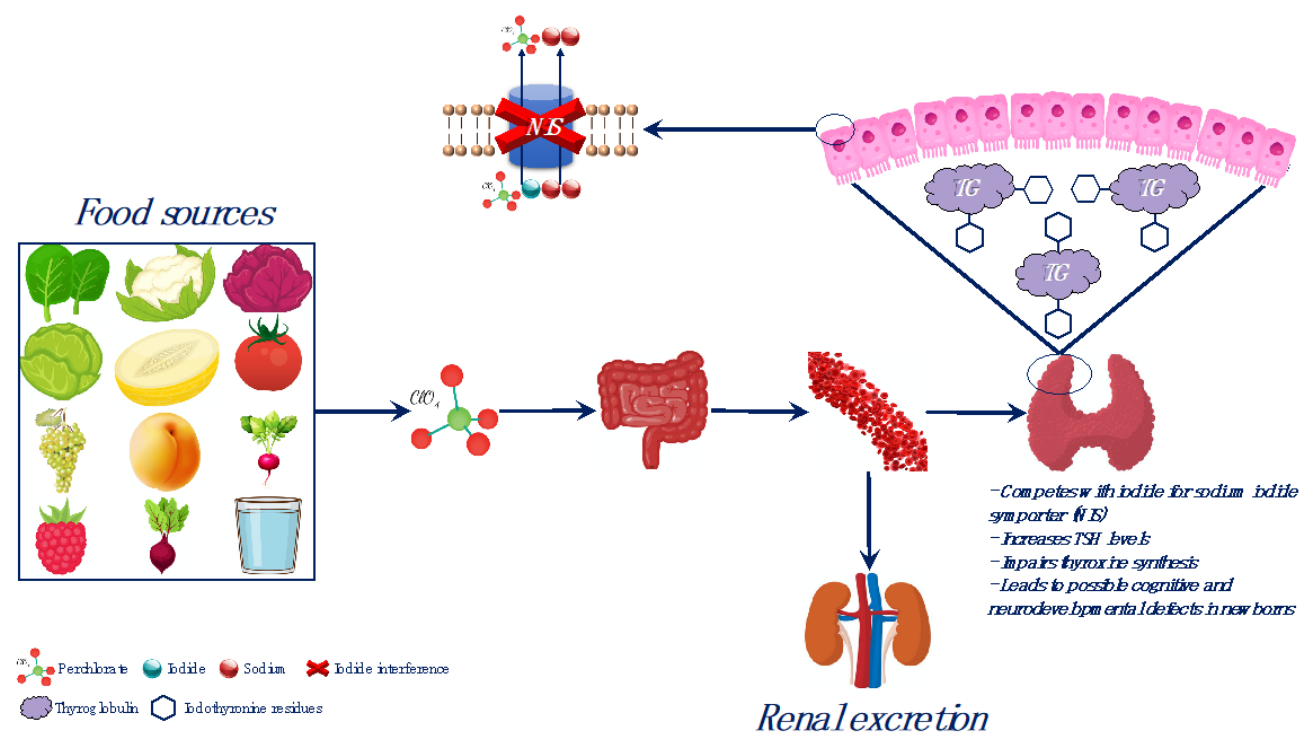

Figure A1. Simplified representation of perchlorate metabolism, distribution and iodide interference (specifically at the level of thyroid gland).

\section{References}

1. Thomas Zoeller, R.; Brown, T.R.; Doan, L.L.; Gore, A.C.; Skakkebaek, N.E.; Soto, A.M.; Woodruff, T.J.; Vom Saal, F.S. Endocrine-disrupting chemicals and public health protection: A statement of principles from the Endocrine Society. Endocrinology 2012, 153, 4097-4110. [CrossRef]

2. La Merrill, M.A.; Vandenberg, L.N.; Smith, M.T.; Goodson, W.; Browne, P.; Patisaul, H.B.; Guyton, K.Z.; Kortenkamp, A.; Cogliano, V.J.; Woodruff, T.J.; et al. Consensus on the key characteristics of endocrine-disrupting chemicals as a basis for hazard identification. Nat. Rev. Endocrinol. 2020, 16, 45-57. [CrossRef] 
3. Langer, P.; Kočan, A.; Tajtáková, M.; Koška, J.; Rádiková, Ž.; Kšinantová, L.; Imrich, R.; Hučková, M.; Drobná, B.; Gašperíková, D.; et al. Increased thyroid volume, prevalence of thyroid antibodies and impaired fasting glucose in young adults from organochlorine cocktail polluted area: Outcome of transgenerational transmission? Chemosphere 2008, 73, 1145-1150. [CrossRef]

4. Street, M.E.; Angelini, S.; Bernasconi, S.; Burgio, E.; Cassio, A.; Catellani, C.; Cirillo, F.; Deodati, A.; Fabbrizi, E.; Fanos, V.; et al. Current knowledge on endocrine disrupting chemicals (EDCs) from animal biology to humans, from pregnancy to adulthood: Highlights from a national italian meeting. Int. J. Mol. Sci. 2018, 19, 1647. [CrossRef] [PubMed]

5. Ferrari, S.M.; Fallahi, P.; Antonelli, A.; Benvenga, S. Environmental issues in thyroid diseases. Front. Endocrinol. 2017, 8, 50. [CrossRef]

6. Yilmaz, B.; Terekeci, H.; Sandal, S.; Kelestimur, F. Endocrine disrupting chemicals: Exposure, effects on human health, mechanism of action, models for testing and strategies for prevention. Rev. Endocr. Metab. Disord. 2019, 21, 127-147. [CrossRef]

7. Boas, M.; Feldt-Rasmussen, U.; Main, K.M. Thyroid effects of endocrine disrupting chemicals. Mol. Cell. Endocrinol. 2012, 355, 240-248. [CrossRef] [PubMed]

8. Calsolaro, V.; Pasqualetti, G.; Niccolai, F.; Caraccio, N.; Monzani, F. Thyroid disrupting chemicals. Int. J. Mol. Sci. 2017, 18, 2583. [CrossRef] [PubMed]

9. Mughal, B.B.; Fini, J.B.; Demeneix, B.A. Thyroid-disrupting chemicals and brain development: An update. Endocr. Connect. 2018, 7, R160-R186. [CrossRef] [PubMed]

10. Melzer, D.; Rice, N.; Depledge, M.H.; Henley, W.E.; Galloway, T.S. Association between serum perfluorooctanoic acid (PFOA) and thyroid disease in the U.S. National Health and Nutrition Examination Survey. Environ. Health Perspect. 2010, 118, 686-692. [CrossRef]

11. MacKay, H.; Abizaid, A. A plurality of molecular targets: The receptor ecosystem for bisphenol-A (BPA). Horm. Behav. 2018, 101, 59-67. [CrossRef] [PubMed]

12. Wang, N.; Zhou, Y.; Fu, C.; Wang, H.; Huang, P.; Wang, B.; Su, M.; Jiang, F.; Fang, H.; Zhao, Q.; et al. Influence of Bisphenol A on Thyroid Volume and Structure Independent of Iodine in School Children. PLoS ONE 2015, 10, e0141248. [CrossRef]

13. Li, L.; Ying, Y.; Zhang, C.; Wang, W.; Li, Y.; Feng, Y.; Liang, J.; Song, H.; Wang, Y. Bisphenol A exposure and risk of thyroid nodules in Chinese women: A case-control study. Environ. Int. 2019, 126, 321-328. [CrossRef] [PubMed]

14. Leemans, M.; Couderq, S.; Demeneix, B.; Fini, J.B. Pesticides With Potential Thyroid Hormone-Disrupting Effects: A Review of Recent Data. Front. Endocrinol. 2019, 10, 743. [CrossRef] [PubMed]

15. Campos, É.; Freire, C. Exposure to non-persistent pesticides and thyroid function: A systematic review of epidemiological evidence. Int. J. Hyg. Environ. Health 2016, 219, 481-497. [CrossRef] [PubMed]

16. Witorsch, R.J. Critical analysis of endocrine disruptive activity of triclosan and its relevance to human exposure through the use of personal care products. Crit. Rev. Toxicol. 2014, 44, 535-555. [CrossRef] [PubMed]

17. Demeneix, B.A. Evidence for Prenatal Exposure to Thyroid Disruptors and Adverse Effects on Brain Development. Eur. Thyroid J. 2019, 8, 283-292. [CrossRef]

18. Pearce, E.N.; Braverman, L.E. Environmental pollutants and the thyroid. Best Pract. Res. Clin. Endocrinol. Metab. 2009, 23, 801-813. [CrossRef]

19. Pironi, L.; Guidetti, M.; Agostini, F. Iodine status in intestinal failure in adults. Curr. Opin. Clin. Nutr. Metab. Care 2015, 18, 582-587. [CrossRef] [PubMed]

20. Nicola, J.P.; Carrasco, N.; Masini-Repiso, A.M. Dietary I- Absorption: Expression and Regulation of the $\mathrm{Na}+/ \mathrm{I}-$ Symporter in the Intestine. Vitam. Horm. 2015, 98, 1-31.

21. Cavalieri, R.R. Iodine metabolism and thyroid physiology: Current concepts. Thyroid 1997, 7, $177-181$. [CrossRef] [PubMed]

22. Ravera, S.; Reyna-Neyra, A.; Ferrandino, G.; Amzel, L.M.; Carrasco, N. The Sodium/Iodide Symporter (NIS): Molecular Physiology and Preclinical and Clinical Applications. Annu. Rev. Physiol. 2017, 79, 261-289. [CrossRef] [PubMed]

23. Dai, G.; Levy, O.; Carrasco, N. Cloning and characterization of the thyroid iodide transporter. Nature 1996, 379, 458-460. [CrossRef] [PubMed]

24. Carrasco, N. Iodide transport in the thyroid gland. BBA Rev. Biomembr. 1993, 1154, 65-82. [CrossRef] 
25. Milanesi, A.; Brent, G.A. Iodine and Thyroid Hormone Synthesis, Metabolism, and Action. Mol. Genet. Nutr. Asp. Major Trace Miner. 2017, 143-150.

26. Lee, S.Y.; Chang, D.L.F.; He, X.; Pearce, E.N.; Braverman, L.E.; Leung, A.M. Urinary iodine excretion and serum thyroid function in adults after iodinated contrast administration. Thyroid 2015, 25, 471-477. [CrossRef]

27. Dunn, J.T.; Dunn, A.D. Update on intrathyroidal iodine metabolism. Thyroid 2001, 11, 407-414. [CrossRef]

28. Rohner, F.; Zimmermann, M.; Jooste, P.; Pandav, C.; Caldwell, K.; Raghavan, R.; Raiten, D.J. Biomarkers of Nutrition for Development-Iodine Review. J. Nutr. 2014, 144, 1322S-1342S. [CrossRef]

29. Glinoer, D. The regulation of thyroid function in pregnancy: Pathways of endocrine adaptation from physiology to pathology. Endocr. Rev. 1997, 18, 404-433. [CrossRef]

30. Osei, J.; Andersson, M.; van der Reijden, O.; Dold, S.; Smuts, C.M.; Baumgartner, J. Breast-milk iodine concentrations, iodine status, and thyroid function of breastfed infants aged $2-4$ months and their mothers residing in a south african township. JCRPE J. Clin. Res. Pediatr. Endocrinol. 2016, 8, 381-391. [CrossRef]

31. Guideline: Fortification of Food-Grade Salt with Iodine for the Prevention and Control of Iodine Deficiency Disorders. Available online: https://www.who.int/publications-detail/9789241507929 (accessed on 3 June 2020).

32. De Groot, L.; Abalovich, M.; Alexander, E.K.; Amino, N.; Barbour, L.; Cobin, R.H.; Eastman, C.J.; Lazarus, J.H.; Luton, D.; Mandel, S.J.; et al. Management of thyroid dysfunction during pregnancy and postpartum: An endocrine society clinical practice guideline. J. Clin. Endocrinol. Metab. 2012, 97, 2543-2565. [CrossRef] [PubMed]

33. Triggiani, V.; Tafaro, E.; Giagulli, V.; Sabba, C.; Resta, F.; Licchelli, B.; Guastamacchia, E. Role of Iodine, Selenium and Other Micronutrients in Thyroid Function and Disorders. Endocr. Metab. Immune Disord. Drug Targets 2009, 9, 277-294. [CrossRef] [PubMed]

34. Guastamacchia, E.; Giagulli, V.; Licchelli, B.; Triggiani, V. Selenium and Iodine in Autoimmune Thyroiditis. Endocr. Metab. Immune Disord. Targets 2015, 15, 288-292. [CrossRef] [PubMed]

35. Bizhanova, A.; Kopp, P. Minireview: The sodium-iodide symporter NIS and pendrin in iodide homeostasis of the thyroid. Endocrinology 2009, 150, 1084-1090. [CrossRef] [PubMed]

36. Wémeau, J.L.; Kopp, P. Pendred syndrome. Best Pract. Res. Clin. Endocrinol. Metab. 2017, 31, $213-224$. [CrossRef]

37. Leung, A.M.; Braverman, L.E. Consequences of excess iodine. Nat. Rev. Endocrinol. 2014, 10, $136-142$. [CrossRef]

38. Sundick, R.S.; Bagchi, N.; Brown, T.R. The role of iodine in thyroid autoimmunity: From chickens to humans: A review. Autoimmunity 1992, 13, 61-68. [CrossRef]

39. Katagiri, R.; Yuan, X.; Kobayashi, S.; Sasaki, S. Effect of excess iodine intake on thyroid diseases in different populations: A systematic review and meta-analyses including observational studies. PLoS ONE 2017, 12, e0173722. [CrossRef]

40. Stanbury, J.B.; Wyngaarden, J.B. Effect of perchlorate on the human thyroid gland. Metabolism 1952, 1, 533-539.

41. Leung, A.M.; Pearce, E.N.; Braverman, L.E. Perchlorate, iodine and the thyroid. Best Pract. Res. Clin. Endocrinol. Metab. 2010, 24, 133-141. [CrossRef]

42. Tonacchera, M.; Pinchera, A.; Dimida, A.; Ferrarini, E.; Agretti, P.; Vitti, P.; Santini, F.; Crump, K.; Gibbs, J. Relative potencies and additivity of perchlorate, thiocyanate, nitrate, and iodide on the inhibition of radioactive iodide uptake by the human sodium iodide symporter. Thyroid 2004, 14, 1012-1019. [CrossRef] [PubMed]

43. Concilio, S.C.; Zhekova, H.R.; Noskov, S.Y.; Russell, S.J. Inter-species variation in monovalent anion substrate selectivity and inhibitor sensitivity in the sodium iodide symporter (NIS). PLoS ONE 2020, 15, e0229085. [CrossRef] [PubMed]

44. Chen, H.X.; Ding, M.H.; Li, Y.G.; Liu, Q.; Peng, K.L. Dose-Response Relationship between Orally Administered Ammonium Perchlorate and Urine Perchlorate Concentrations in Rats: Possible Biomarker to Quantify Environmental Ammonium Perchlorate Exposure on Thyroid Homeostasis. Arch. Environ. Occup. Health 2015, 70, 286-290. [CrossRef] [PubMed]

45. Hershman, J.M. Perchlorate and thyroid function: What are the environmental issues? Thyroid 2005, 15, 427-431. [CrossRef] 
46. Suh, M.; Abraham, L.; Hixon, J.G.; Proctor, D.M. The effects of perchlorate, nitrate, and thiocyanate on free thyroxine for potentially sensitive subpopulations o. The 2001-2002 and 2007-2008 National Health and Nutrition Examination Surveys. J. Expo. Sci. Environ. Epidemiol. 2014, 24, 579-587. [CrossRef]

47. EFSA Panel on Contaminants in the Food Chain (CONTAM). Scientific Opinion on the risks to public health related to the presence of perchlorate in food, in particular fruits and vegetables. EFSA J. 2014, 12, 3869. [CrossRef]

48. Kounaves, S.P.; Stroble, S.T.; Anderson, R.M.; Moore, Q.; Catling, D.C.; Douglas, S.; Mckay, C.P.; Ming, D.W.; Smith, P.H.; Tamppari, L.K.; et al. Discovery of natural Perchlorate in the Antarctic Dry Valleys and its global implications. Environ. Sci. Technol. 2010, 44, 2360-2364. [CrossRef]

49. Calderón, R.; Palma, P.; Parker, D.; Molina, M.; Godoy, F.A.; Escudey, M. Perchlorate levels in soil and waters from the Atacama Desert. Arch. Environ. Contam. Toxicol. 2014, 66, 155-161. [CrossRef]

50. Kumarathilaka, P.; Oze, C.; Indraratne, S.P.; Vithanage, M. Perchlorate as an emerging contaminant in soil, water and food. Chemosphere 2016, 150, 667-677. [CrossRef]

51. Furdui, V.I.; Zheng, J.; Furdui, A. Anthropogenic Perchlorate Increases since 1980 in the Canadian High Arctic. Environ. Sci. Technol. 2018, 52, 972-981. [CrossRef]

52. Furdui, V.I.; Tomassini, F. Trends and sources of perchlorate in Arctic snow. Environ. Sci. Technol. 2010, 44, 588-592. [CrossRef] [PubMed]

53. Dasgupta, P.K.; Martinelango, P.K.; Jackson, W.A.; Anderson, T.A.; Tian, K.; Tock, R.W.; Rajagopalan, S. The origin of naturally occurring perchlorate: The role of atmospheric processes. Environ. Sci. Technol. 2005, 39, 1569-1575. [CrossRef]

54. Kannan, K.; Praamsma, M.L.; Oldi, J.F.; Kunisue, T.; Sinha, R.K. Occurrence of perchlorate in drinking water, groundwater, surface water and human saliva from India. Chemosphere 2009, 76, 22-26. [CrossRef]

55. Qin, X.; Zhang, T.; Gan, Z.; Sun, H. Spatial distribution of perchlorate, iodide and thiocyanate in the aquatic environment of Tianjin, China: Environmental source analysis. Chemosphere 2014, 111, 201-208. [CrossRef] [PubMed]

56. Munster, J.; Hanson, G.N.; Jackson, W.A.; Rajagopalan, S. The fallout from fireworks: Perchlorate in total deposition. Water Air Soil Pollut. 2009, 198, 149-153. [CrossRef]

57. Rajagopalan, S.; Anderson, T.; Cox, S.; Harvey, G.; Cheng, Q.; Jackson, W.A. Perchlorate in Wet Deposition Across North America. Environ. Sci. Technol. 2009, 43, 616-622. [CrossRef] [PubMed]

58. Urbansky, E.T.; Brown, S.K. Perchlorate retention and mobility in soils. J. Environ. Monit. 2003, 5, 455-462. [CrossRef]

59. Dugan, N.R.; Williams, D.J.; Meyer, M.; Schneider, R.R.; Speth, T.F.; Metz, D.H. The impact of temperature on the performance of anaerobic biological treatment of perchlorate in drinking water. Water Res. 2009, 43, 1867-1878. [CrossRef]

60. Calderón, R.; Palma, P.; Eltit, K.; Arancibia-Miranda, N.; Silva-Moreno, E.; Yu, W. Field study on the uptake, accumulation and risk assessment of perchlorate in a soil-chard/spinach system: Impact of agronomic practices and fertilization. Sci. Total Environ. 2020, 719, 137411. [CrossRef]

61. Calderón, R.; Godoy, F.; Escudey, M.; Palma, P. A review of perchlorate (ClO4-) occurrence in fruits and vegetables. Environ. Monit. Assess. 2017, 189, 82. [CrossRef]

62. Wang, Z.; Forsyth, D.; Lau, B.P.Y.; Pelletier, L.; Bronson, R.; Gaertner, D. Estimated dietary exposure of canadians to perchlorate through the consumption of fruits and vegetables available in Ottawa markets. J. Agric. Food Chem. 2009, 57, 9250-9255. [CrossRef] [PubMed]

63. Vega, M.; Nerenberg, R.; Vargas, I.T. Perchlorate contamination in Chile: Legacy, challenges, and potential solutions. Environ. Res. 2018, 164, 316-326. [CrossRef]

64. Steinmaus, C.M. Perchlorate in Water Supplies: Sources, Exposures, and Health Effects. Curr. Environ. Health Rep. 2016, 3, 136-143. [CrossRef] [PubMed]

65. Iannece, P.; Motta, O.; Tedesco, R.; Carotenuto, M.; Proto, A. Determination of Perchlorate in Bottled Water from Italy. Water 2013, 5, 767-779. [CrossRef]

66. Agrarmarkt Informations-Gesellschaft MbH. European Statistics Handbook-FRUIT LOGISTICA 2019. Available online: www.AMI-informiert.de (accessed on 2 March 2020).

67. OEC. Chile (CHL) Exports, Imports, and Trade Partners. Available online: https://oec.world/en/profile/ country/chl/ (accessed on 11 May 2020). 
68. Chilean Table Grape Exports to Europe Increase by 36\%. Available online: https://www.freshplaza.com/ article/9196058/chilean-table-grape-exports-to-europe-increase-by-36/ (accessed on 11 May 2020).

69. Chile-Trade-European Commission. Available online: https://ec.europa.eu/trade/policy/countries-andregions/countries/chile/ (accessed on 11 May 2020).

70. Arcella, D.; Binaglia, M.; Vernazza, F. Dietary exposure assessment to perchlorate in the European population. EFSA J. 2017, 15, e05043.

71. Dong, H.; Xiao, K.; Xian, Y.; Wu, Y.; Zhu, L. A novel approach for simultaneous analysis of perchlorate (ClO4-) and bromate (BrO3-) in fruits and vegetables using modified QuEChERS combined with ultrahigh performance liquid chromatography-tandem mass spectrometry. Food Chem. 2019, 270, 196-203. [CrossRef]

72. Vejdovszky, K.; Grossgut, R.; Unterluggauer, H.; Inreiter, N.; Steinwider, J. Risk assessment of dietary exposure to perchlorate for the Austrian population. Food Addit. Contam. Part A Chem. Anal. Control. Expo. Risk Assess. 2018, 35, 623-631. [CrossRef]

73. Liu, Y.; Sun, H.; Zhou, L.; Luo, F.; Zhang, X.; Chen, Z. Quantitative determination and contamination pattern of perchlorate in tea by ultra performance liquid chromatography and tandem mass spectrometry. Food Chem. 2019, 274, 180-186. [CrossRef]

74. Huber, D.R.; Blount, B.C.; Mage, D.T.; Letkiewicz, F.J.; Kumar, A.; Allen, R.H. Estimating perchlorate exposure from food and tap water based on US biomonitoring and occurrence data. J. Expo. Sci. Environ. Epidemiol. 2011, 21, 395-407. [CrossRef]

75. Blount, B.C.; Valentin-Blasini, L.; Osterloh, J.D.; Mauldin, J.P.; Pirkle, J.L. Perchlorate exposure of the US population, 2001-2002. J. Expo. Sci. Environ. Epidemiol. 2007, 17, 400-407. [CrossRef]

76. Zoeller, T.R. Environmental chemicals targeting thyroid. Hormones 2010, 9, 28-40. [CrossRef]

77. Vandenberg, L.N.; Colborn, T.; Hayes, T.B.; Heindel, J.J.; Jacobs, D.R.; Lee, D.H.; Shioda, T.; Soto, A.M.; vom Saal, F.S.; Welshons, W.V.; et al. Hormones and endocrine-disrupting chemicals: Low-dose effects and nonmonotonic dose responses. Endocr. Rev. 2012, 33, 378-455. [CrossRef] [PubMed]

78. Lee, S.Y.; McCarthy, A.M.; Stohl, H.; Ibrahim, S.; Jeong, C.; Braverman, L.E.; Ma, W.; He, X.; Mestman, J.H.; Schuller, K.E.; et al. Urinary Iodine, Perchlorate, and Thiocyanate Concentrations in U.S. Lactating Women. Thyroid 2017, 27, 1574-1581. [CrossRef] [PubMed]

79. Leung, A.M.; LaMar, A.; He, X.; Braverman, L.E.; Pearce, E.N. Iodine status and thyroid function of Boston-area vegetarians and vegans. J. Clin. Endocrinol. Metab. 2011, 96, E1303-E1307. [CrossRef] [PubMed]

80. De Groef, B.; Decallonne, B.R.; Van der Geyten, S.; Darras, V.M.; Bouillon, R. Perchlorate versus other environmental sodium/iodide symporter inhibitors: Potential thyroid-related health effects. Eur. J. Endocrinol. 2006, 155, 17-25. [CrossRef]

81. Téllez, R.T.; Chacón, P.M.; Abarca, C.R.; Blount, B.C.; Van Landingham, C.B.; Crump, K.S.; Gibbs, J.P. Long-term environmental exposure to perchlorate through drinking water and thyroid function during pregnancy and the neonatal period. Thyroid 2005, 15, 963-975. [CrossRef]

82. Maffini, M.V.; Trasande, L.; Neltner, T.G. Perchlorate and Diet: Human Exposures, Risks, and Mitigation Strategies. Curr. Environ. Health Rep. 2016, 3, 107-117. [CrossRef]

83. Borjan, M.; Marcella, S.; Blount, B.; Greenberg, M.; Zhang, J.; Murphy, E.; Valentin-Blasini, L.; Robson, M. Perchlorate exposure in lactating women in an urban community in New Jersey. Sci. Total Environ. 2011, 409, 460-464. [CrossRef]

84. Zhang, T.; Wu, Q.; Sun, H.W.; Rao, J.; Kannan, K. Perchlorate and iodide in whole blood samples from infants, children, and adults in Nanchang, China. Environ. Sci. Technol. 2010, 44, 6947-6953. [CrossRef]

85. Valentín-Blasini, L.; Blount, B.C.; Otero-Santos, S.; Cao, Y.; Bernbaum, J.C.; Rogan, W.J. Perchlorate exposure and dose estimates in infants. Environ. Sci. Technol. 2011, 45, 4127-4132. [CrossRef]

86. Lau, F.K.; Decastro, B.R.; Mills-Herring, L.; Tao, L.; Valentin-Blasini, L.; Alwis, K.U.; Blount, B.C. Urinary perchlorate as a measure of dietary and drinking water exposure in a representative sample of the United States population 2001-2008. J. Expo. Sci. Environ. Epidemiol. 2013, 23, 207-214. [CrossRef]

87. Crump, C.; Michaud, P.; Téllez, R.; Reyes, C.; Gonzalez, G.; Montgomery, E.L.; Crump, K.S.; Lobo, G.; Becerra, C.; Gibbs, J.P. Does perchlorate in drinking water affect thyroid function in newborns or school-age children? J. Occup. Environ. Med. 2000, 42, 603-612. [CrossRef] [PubMed]

88. Levie, D.; Korevaar, T.I.M.; Bath, S.C.; Murcia, M.; Dineva, M.; Llop, S.; Espada, M.; van Herwaarden, A.E.; de Rijke, Y.B.; Ibarluzea, J.M.; et al. Association of Maternal Iodine Status With Child IQ: A Meta-Analysis of Individual Participant Data. J. Clin. Endocrinol. Metab. 2019, 104, 5957-5967. [CrossRef] [PubMed] 
89. Knight, B.A.; Shields, B.M.; He, X.; Pearce, E.N.; Braverman, L.E.; Sturley, R.; Vaidya, B. Effect of perchlorate and thiocyanate exposure on thyroid function of pregnant women from South-West England: A cohort study. Thyroid Res. 2018, 11, 9. [CrossRef] [PubMed]

90. Mitchell, A.M.; Manley, S.W.; Morris, J.C.; Powell, K.A.; Bergert, E.R.; Mortimer, R.H. Sodium iodide symporter (NIS) gene expression in human placenta. Placenta 2001, 22, 256-258. [CrossRef] [PubMed]

91. Blount, B.C.; Rich, D.Q.; Valentin-Blasini, L.; Lashley, S.; Ananth, C.V.; Murphy, E.; Smulian, J.C.; Spain, B.J.; Barr, D.; Ledoux, T.; et al. Perinatal exposure to perchlorate, thiocyanate, and nitrate in New Jersey mothers and newborns. Environ. Sci. Technol. 2009, 43, 7543-7549. [CrossRef]

92. Zhang, T.; Ma, Y.; Wang, D.; Li, R.; Chen, X.; Mo, W.; Qin, X.; Sun, H.; Kannan, K. Placental transfer of and infantile exposure to perchlorate. Chemosphere 2016, 144, 948-954. [CrossRef]

93. Pearce, E.N.; Alexiou, M.; Koukkou, E.; Braverman, L.E.; He, X.; Ilias, I.; Alevizaki, M.; Markou, K.B. Perchlorate and thiocyanate exposure and thyroid function in first-trimester pregnant women from Greece. Clin. Endocrinol. 2012, 77, 471-474. [CrossRef]

94. Charatcharoenwitthaya, N.; Ongphiphadhanakul, B.; Pearce, E.N.; Somprasit, C.; Chanthasenanont, A.; He, X.; Chailurkit, L.; Braverman, L.E. The association between perchlorate and thiocyanate exposure and thyroid function in first-trimester pregnant Thai women. J. Clin. Endocrinol. Metab. 2014, 99, 2365-2371. [CrossRef]

95. Steinmaus, C.; Pearl, M.; Kharrazi, M.; Blount, B.C.; Miller, M.D.; Pearce, E.N.; Valentin-Blasini, L.; DeLorenze, G.; Hoofnagle, A.N.; Liaw, J. Thyroid hormones and moderate exposure to perchlorate during pregnancy in women in southern California. Environ. Health Perspect. 2016, 124, 861-867. [CrossRef]

96. Pearce, E.N.; Lazarus, J.H.; Smyth, P.P.A.; He, X.; Dall'Amico, D.; Parkes, A.B.; Burns, R.; Smith, D.F.; Maina, A.; Bestwick, J.P.; et al. Perchlorate and thiocyanate exposure and thyroid function in first-trimester pregnant women. J. Clin. Endocrinol. Metab. 2010, 95, 3207-3215. [CrossRef] [PubMed]

97. Pearce, E.N.; Spencer, C.A.; Mestman, J.H.; Lee, R.H.; Bergoglio, L.M.; Mereshian, P.; He, X.; Leung, A.M.; Braverman, L.E. Effect of environmental perchlorate on thyroid function in pregnant women from Córdoba, Argentina, and Los Angeles, California. Endocr. Pract. 2011, 17, 412-417. [CrossRef] [PubMed]

98. Horton, M.K.; Blount, B.C.; Valentin-Blasini, L.; Wapner, R.; Whyatt, R.; Gennings, C.; Factor-Litvak, P. $\mathrm{CO}$-occurring exposure to perchlorate, nitrate and thiocyanate alters thyroid function in healthy pregnant women. Environ. Res. 2015, 143, 1-9. [CrossRef] [PubMed]

99. Taylor, P.N.; Okosieme, O.E.; Murphy, R.; Hales, C.; Chiusano, E.; Maina, A.; Joomun, M.; Bestwick, J.P.; Smyth, P.; Paradice, R.; et al. Maternal perchlorate levels in women with borderline thyroid function during pregnancy and the cognitive development of their offspring: Data from the controlled antenatal thyroid study. J. Clin. Endocrinol. Metab. 2014, 99, 4291-4298. [CrossRef]

100. Brent, G.A. Perchlorate exposure in pregnancy and cognitive outcomes in children: It's not your mother's thyroid. J. Clin. Endocrinol. Metab. 2014, 99, 4066-4068. [CrossRef]

101. Rubin, R.; Pearl, M.; Kharrazi, M.; Blount, B.C.; Miller, M.D.; Pearce, E.N.; Valentin-Blasini, L.; DeLorenze, G.; Liaw, J.; Hoofnagle, A.N.; et al. Maternal perchlorate exposure in pregnancy and altered birth outcomes. Environ. Res. 2017, 158, 72-81. [CrossRef]

102. Buffler, P.A.; Kelsh, M.A.; Lau, E.C.; Edinboro, C.H.; Barnard, J.C.; Rutherford, G.W.; Daaboul, J.J.; Palmer, L.; Lorey, F.W. Thyroid function and perchlorate in drinking water: An evaluation among California newborns, 1998. Environ. Health Perspect. 2006, 114, 798-804. [CrossRef]

103. Amitai, Y.; Winston, G.; Sack, J.; Wasser, J.; Lewis, M.; Blount, B.C.; Valentin-Blasini, L.; Fisher, N.; Israeli, A.; Leventhal, A. Gestational exposure to high perchlorate concentrations in drinking water and neonatal thyroxine levels. Thyroid 2007, 17, 843-850. [CrossRef]

104. Steinmaus, C.; Miller, M.D.; Smith, A.H. Perchlorate in drinking water during pregnancy and neonatal thyroid hormone levels in California. J. Occup. Environ. Med. 2010, 52, 1217-1224. [CrossRef]

105. Mervish, N.A.; Pajak, A.; Teitelbaum, S.L.; Pinney, S.M.; Windham, G.C.; Kushi, L.H.; Biro, F.M.; Valentin-Blasini, L.; Blount, B.C.; Wolff, M.S. Thyroid antagonists (perchlorate, thiocyanate, and nitrate) and childhood growth in a longitudinal study of U.S. girls. Environ. Health Perspect. 2016, 124, 542-549. [CrossRef]

106. McMullen, J.; Ghassabian, A.; Kohn, B.; Trasande, L. Identifying subpopulations vulnerable to the thyroid-blocking effectsof perchlorateandthiocyanate. J. Clin. Endocrinol. Metab. 2017, 102, 2637-2645. [CrossRef] [PubMed] 
107. Van Sande, J.; Massart, C.; Beauwens, R.; Schoutens, A.; Costagliola, S.; Dumont, J.E.; Wolff, J. Anion selectivity by the sodium iodide symporter. Endocrinology 2003, 144, 247-252. [CrossRef] [PubMed]

108. Jianjie, C.; Wenjuan, X.; Jinling, C.; Jie, S.; Ruhui, J.; Meiyan, L. Fluoride caused thyroid endocrine disruption in male zebrafish (Danio rerio). Aquat. Toxicol. 2016, 171, 48-58. [CrossRef] [PubMed]

109. Yoffe, D.; Frim, R.; Ukeles, S.D.; Dagani, M.J.; Barda, H.J.; Benya, T.J.; Sanders, D.C. Bromine Compounds. In Ullmann's Encyclopedia of Industrial Chemistry; Wiley-VCH Verlag GmbH \& Co. KGaA: Weinheim, Germany, 2013; pp. 1-31.

110. Bromine as a Drinking-Water Disinfectant Alternative Drinking-Water Disinfectants: Bromine. 2018. Available online: http://apps.who.int/bookorders (accessed on 27 May 2020).

111. Thewlis, B.H. The fate of potassium bromate when used as a breadmaking improver. J. Sci. Food Agric. 1974, 25, 1471-1475. [CrossRef]

112. Shanmugavel, V.; Komala Santhi, K.; Kurup, A.H.; Kalakandan, S.; Anandharaj, A.; Rawson, A. Potassium bromate: Effects on bread components, health, environment and method of analysis: A review. Food Chem. 2020, 311, 125964. [CrossRef] [PubMed]

113. Mitsumori, K.; Maita, K.; Kosaka, T.; Miyaoka, T.; Shirasu, Y. Two-year oral chronic toxicity and carcinogenicity study in rats of diets fumigated with methyl bromide. Food Chem. Toxicol. 1990, 28, 109-119. [CrossRef]

114. Kurokawa, Y.; Maekawa, A.; Takahashi, M.; Hayashi, Y. Toxicity and carcinogenicity of potassium bromate-A new renal carcinogen. Environ. Health Perspect. 1990, 87, 309-335.

115. Umemura, T.; Sai, K.; Takagi, A.; Hasegawa, R.; Kurokawa, Y. A possible role for cell proliferation in potassium bromate (KBrO3) carcinogenesis. J. Cancer Res. Clin. Oncol. 1993, 119, 463-469. [CrossRef]

116. Last eval.: Potassium Bromate (IARC Summary \& Evaluation, Volume 73, 1999). Available online: http://www.inchem.org/documents/iarc/vol73/73-17.html (accessed on 31 May 2020).

117. FDA CFR - Code of Federal Regulations Title 21. Available online: https://www.accessdata.fda.gov/scripts/ cdrh/cfdocs/cfcfr/CFRSearch.cfm?fr=172.730 (accessed on 31 May 2020).

118. Wu, Z.; He, C.; Han, W.; Song, J.; Li, H.; Zhang, Y.; Jing, X.; Wu, W. Exposure pathways, levels and toxicity of polybrominated diphenyl ethers in humans: A review. Environ. Res. 2020, 187, 109531. [CrossRef]

119. Pavelka, S. Metabolism of Bromide and Its Interference With the Metabolism of Iodine. Physiol. Res. 2004, 53 (Suppl. 1), S81-S90.

120. Block, J. Nineteenth-Century Homeopathic Materia Medica Texts Predict Source Materials Whose Physiological Actions Influence Thyroid Activity. Homeopathy 2019, 108, 214-222. [CrossRef] [PubMed]

121. Yadav, K.K.; Gupta, N.; Kumar, V.; Khan, S.A.; Kumar, A. A review of emerging adsorbents and current demand for defluoridation of water: Bright future in water sustainability. Environ. Int. 2018, 111, 80-108. [CrossRef] [PubMed]

122. Kurwadkar, S. Occurrence and distribution of organic and inorganic pollutants in groundwater. Water Environ. Res. 2019, 91, 1001-1008. [CrossRef] [PubMed]

123. La Fluorazione Delle Acque in Italia. Available online: https://www.epicentro.iss.it/cavo_orale/nota (accessed on 27 May 2020).

124. WHO. Water-Related Diseases. Available online: https://www.who.int/water_sanitation_health/diseasesrisks/diseases/fluorosis/en/ (accessed on 31 May 2020).

125. Srivastava, S.; Flora, S.J.S. Fluoride in Drinking Water and Skeletal Fluorosis: A Review of the Global Impact. Curr. Environ. Health Rep. 2020, 7. [CrossRef]

126. Waugh, D.T. Fluoride exposure induces inhibition of sodium/iodide symporter (NIS) contributing to impaired iodine absorption and iodine deficiency: Molecular mechanisms of inhibition and implications for public health. Int. J. Environ. Res. Public Health 2019, 16, 1086. [CrossRef]

127. Nakamoto, T.; Ralph Rawls, H. Fluoride exposure in early life as the possible root cause of disease in later life. J. Clin. Pediatr. Dent. 2018, 42, 325-330. [CrossRef]

128. Johnston, N.R.; Strobel, S.A. Principles of fluoride toxicity and the cellular response: A review. Arch. Toxicol. 2020, 94, 1051-1069. [CrossRef]

129. Hegde, R.M.; Rego, R.M.; Potla, K.M.; Kurkuri, M.D.; Kigga, M. Bio-inspired materials for defluoridation of water: A review. Chemosphere 2020, 253. [CrossRef]

130. Leung, A.K.C.; Leung, A.A.C. Evaluation and management of the child with hypothyroidism. World J. Pediatr. 2019, 15, 124-134. [CrossRef] 
131. Hay, I.; Hynes, K.L.; Burgess, J.R. Mild-to-moderate gestational iodine deficiency processing disorder. Nutrients 2019, 11, 19674. [CrossRef]

132. Urinary Iodine Concentrations for Determining Iodine Status in Populations. Available online: https: //apps.who.int/iris/bitstream/handle/10665/85972/WHO_NMH_NHD_EPG_13.1_eng.pdf?ua=1 (accessed on 3 June 2020).

133. Zimmermann, M.B. Iodine deficiency. Endocr. Rev. 2009, 30, 376-408. [CrossRef] [PubMed]

134. Baldini, E.; Virili, C.; D'Armiento, E.; Centanni, M.; Ulisse, S. Iodine status in schoolchildren and pregnant women of lazio, a central region of Italy. Nutrients 2019, 11, 1674. [CrossRef] [PubMed]

135. Giordano, C.; Barone, I.; Marsico, S.; Bruno, R.; Bonofiglio, D.; Catalano, S.; Andò, S. Endemic goiter and iodine prophylaxis in calabria, a region of southern Italy: Past and present. Nutrients 2019, 11, 2428. [CrossRef]

136. Zimmermann, M.B.; Andersson, M. Assessment of iodine nutrition in populations: Past, present, and future. Nutr. Rev. 2012. [CrossRef] [PubMed]

137. Li, M.; Eastman, C.J. NATURE REVIEWS | ENDOCRINOLOGY The changing epidemiology of iodine deficiency. Nat. Publ. Gr. 2012. [CrossRef]

138. Soldin, O.P.; Braverman, L.E.; Lamm, S.H. Perchlorate Clinical Pharmacology and Human Health: A Review. Ther. Drug Monit. 2001, 23, 316. [CrossRef]

139. Murray, C.W.; Egan, S.K.; Kim, H.; Beru, N.; Bolger, P.M. US food and drug administration's total diet study: Dietary intake of perchlorate and iodine. J. Expo. Sci. Environ. Epidemiol. 2008, 18, 571-580. [CrossRef]

140. Mantovani, A. Endocrine disrupters and the safety of food chains. Horm. Res. Paediatr. 2016, 86, $279-288$. [CrossRef]

141. Council, N.R. Health Implications of Perchlorate Ingestion. 2005. Available online: https://books.google.com/books?hl=it\&lr=\&id=05F0iOqvwgAC\&oi=fnd\&pg=PR1\&ots=1byRT87Mff\& sig=Kf3cQjhexKXGQ24WspdAKos7iNM (accessed on 10 May 2020).

142. Lawrence, J.; Lamm, S.; Braverman, L.E. Low dose perchlorate (3 mg daily) and thyroid function. Thyroid 2001, 11, 295. [CrossRef] [PubMed]

143. Lawrence, J.E.; Lamm, S.H.; Pino, S.; Richman, K.; Braverman, L.E. The effect of short-term low-dose perchlorate on various aspects of thyroid function. Thyroid 2000, 10, 659-663. [CrossRef]

144. Greer, M.A.; Goodman, G.; Pleus, R.C.; Greer, S.E. Health effects perchlorate contamination: The dose response for inhibition of thyroidal radioiodine uptake in humans. Environ. Health Perspect. 2002, 110,927-937. [CrossRef] [PubMed]

145. Gibbs, J.P.; Ahmad, R.; Crump, K.S.; Houck, D.P.; Leveille, T.S.; Findley, J.E.; Francis, M. Evaluation of a population with occupational exposure to airborne ammonium perchlorate for possible acute or chronic effects on thyroid function. J. Occup. Environ. Med. 1998, 40, 1072-1082. [CrossRef] [PubMed]

146. Lamm, S.H.; Braverman, L.E.; Li, F.X.; Richman, K.; Pino, S.; Howearth, G. Thyroid health status of ammonium perchlorate workers: A cross-sectional occupational health study. J. Occup. Environ. Med. 1999, 41, 248-260. [CrossRef] [PubMed]

147. Braverman, L.E.; He, X.; Pino, S.; Cross, M.; Magnani, B.; Lamm, S.H.; Kruse, M.B.; Engel, A.; Crump, K.S.; Gibbs, J.P. The Effect of Perchlorate, Thiocyanate, and Nitrate on Thyroid Function in Workers Exposed to Perchlorate Long-Term. J. Clin. Endocrinol. Metab. 2005, 90, 700-706. [CrossRef] [PubMed]

148. Alexeeff, G.V.; Rodriquez, M.; Brown Governor, E.G., Jr. Office of Environmental Health Hazard Assessment OEHHA Adopts Updated Public Health Goal for Perchlorate. 2015. Available online: www.oehha.ca.gov (accessed on 10 May 2020).

149. WHO|JECFA. Evaluations of the Joint FAO/WHO Expert Committee on Food Additives (JECFA). Available online: https://apps.who.int/food-additives-contaminants-jecfa-database/chemical.aspx?chemID= 5885 (accessed on 11 May 2020).

150. Srinivasan, A.; Viraraghavan, T. Perchlorate: Health effects and technologies for its removal from water resources. Int. J. Environ. Res. Public Health 2009, 6, 1418-1442. [CrossRef]

151. Batista, J.R.; McGarvey, F.X.; Vieira, A.R. The Removal of Perchlorate from Waters Using Ion-Exchange Resins. In Perchlorate in the Environment; Springer: Boston, MA, USA, 2000; pp. 135-145.

152. Xu, J.; Song, Y.; Min, B.; Steinberg, L.; Logan, B.E. Microbial degradation of perchlorate: Principles and applications. Environ. Eng. Sci. 2003, 20, 405-422. [CrossRef] 
153. Zhao, X.; Zhang, G.; Zhang, Z. TiO2-based catalysts for photocatalytic reduction of aqueous oxyanions: State-of-the-art and future prospects. Environ. Int. 2020, 136. [CrossRef]

154. Han, J.; Kong, C.; Heo, J.; Yoon, Y.; Lee, H.; Her, N. Removal of perchlorate using reverse osmosis and nanofiltration membranes. Environ. Eng. Res. 2012, 17, 185-190. [CrossRef]

155. Roquebert, V.; Booth, S.; Cushing, R.S.; Crozes, G.; Hansen, E. Electrodialysis reversal (EDR) and ion exchange as polishing treatment for perchlorate treatment. Desalination 2000, 131, 285-291. [CrossRef]

156. Kumar, E.; Bhatnagar, A.; Hogland, W.; Marques, M.; Sillanpää, M. Interaction of inorganic anions with iron-mineral adsorbents in aqueous media-A review. Adv. Colloid Interface Sci. 2014, 203, 11-21. [CrossRef]

157. Kumar, E.; Bhatnagar, A.; Ji, M.; Jung, W.; Lee, S.H.; Kim, S.J.; Lee, G.; Song, H.; Choi, J.Y.; Yang, J.S.; et al. Defluoridation from aqueous solutions by granular ferric hydroxide (GFH). Water Res. 2009, 43, 490-498. [CrossRef] [PubMed]

158. Susarla, S.; Collette, T.W.; Garrison, A.W.; Wolfe, N.L.; Mccutcheon, S.C. Perchlorate identification in fertilizers. Environ. Sci. Technol. 1999, 33, 3469-3472. [CrossRef]

159. Calderon, R.; Rajendiran, K.; Kim, U.J.; Palma, P.; Arancibia-Miranda, N.; Silva-Moreno, E.; Corradini, F. Sources and fates of perchlorate in soils in Chile: A case study of perchlorate dynamics in soil-crop systems using lettuce (Lactuca sativa) fields. Environ. Pollut. 2020, 264. [CrossRef] [PubMed]

(C) 2020 by the authors. Licensee MDPI, Basel, Switzerland. This article is an open access article distributed under the terms and conditions of the Creative Commons Attribution (CC BY) license (http://creativecommons.org/licenses/by/4.0/). 